\title{
Haber Edinme Amaçlı Sosyal Medya Kullanım Sıklığının Haber Paylaşma Davranışı Üzzerindeki Rolü: Bir Saha Çalışması
}

\author{
İbrahim Halil YAŞAR ${ }^{1}$ ve Yusuf Zafer Can UĞURHAN ${ }^{2}$
}

Öz

Günümüzde sosyal medya bireysel ve toplumsal yaşamın merkezinde yer alan önemli bir iletişim aracıdır. Sosyal medya sıradan bireyleri birer kitle yayıncısına dönüştürebilme potansiyeline sahiptir. Bireyler sosyal medyanın sunmuş olduğu altyapı ve imkânlar sayesinde, güncel konu ve olaylardan haberdar olurken, aynı zamanda çevrelerinde olup biten ve haber değeri taşıdığını düşündükleri olaylarla ilgili içerik üretip paylaşarak birer kitle yayıncısına dönüşebilmektedir. Dolayısıyla geldiğimiz noktada günümüz bireyi hem haberin alıcısı hem de onun kaynağ1 ve dağıtıcısı durumundadır. Bu çalışmada nicel araştırma yöntemi ve kesitsel tarama modeli kullanılarak, bireyin sosyal medyayı haber edinme ve paylaşma amaçlı kullanımı incelenmiştir. Yapılan inceleme çerçevesinde sosyal medyayı haber edinme amaçlı kullanan bireylerin, bu amaçla hangi sosyal medya platformunu ne sıklıkta kullandıkları belirlenmiştir. Sonrasında kümeleme analizi yapılarak bu sıklıklara göre üç gruplu bir sınıflandırma ortaya çıkarılmıştır. Elde edilen kümeler aracıllğıyla da günümüz bireyinin haber edinme ve paylaşma davranışı anlaşılmaya çalışılmıştır. Sonuç olarak WhatsApp platformu haber edinme amaçlı kullanım açısından görece daha öne çıarken, haber edinme amaçlı sosyal medya kullanım sıklığı arttığında haber paylaşma eğilimi de yükselmektedir. Demografik özellikler ile haber edinme sıklığı arasında anlamlı ilişkiler söz konusuyken, demografik özelliklerin haber paylaşma davranışı üzerinde anlamlı bir rolü yoktur.

Anabtar Kelimeler: Sosyal Medya, Haber Edinme, Haber Paylaşma, Kümeleme Analizi

The Role of Social Media Usage Frequency for Getting News on News Sharing Behavior: A Field Study

\section{Abstract}

Today, social media is a fundamental communication tool that is at the center of individual and social life. Social media has a potential to transform ordinary individuals into mass streamers. Thanks to opportunities provided by social media, individuals can become aware of current issues and events in a short time. They can also turn into mass streamers by producing and sharing contents. Thus, today's individual is both the receiver, source and, the distributer of the news. A cross-sectional quantitative research method was employed to examine the individual's use of social media for acquiring and sharing news. It was determined which social media platforms and how often were they used by the individuals. Afterwards, a cluster analysis was performed and a classification with three groups was created. The behavior of acquiring and sharing the news of today's individuals has been scrutinized Through the clusters obtained. As a result of the study, it is indicated that while WhatsApp stood out relatively more in terms of its use to get news, the tendency to share news also increased with the increasing frequency of social media use for news purposes. However, while there were significant relationships between demographics and the frequency of getting news, there was no significant role of demographics on news sharing behavior.

Key Words: Social Media, Getting News, News Sharing, Cluster Analysis

Atıf İçin / Please Cite As:

Yaşar, İ. H. ve Uğurhan, Y. Z. C. (2021). Haber edinme amaçlı sosyal medya kullanım sıklı̆̆ının haber paylaşma davranışı üzerindeki rolü: Bir saha çalışması. Manas Sosyal Araştırmalar Dergisi, 10(2), 1182-1198.

Geliş Tarihi / Received Date: 13.08 .2020

Kabul Tarihi / Accepted Date: 24.12.2020

\footnotetext{
${ }^{1}$ Arş. Gör. Dr. - Dicle Üniversitesi İletişim Fakültesi, i.halilyasar@hotmail.com

(iD ORCID: 0000-0002-1480-569X

2 Öğr. Gör. - Anadolu Üniversitesi Açıöŏgretim Fakültesi, yzcu@anadolu.edu.tr

iD ORCID: 0000-0003-1264-9002
} 


\section{Giriş}

Günümüzde her türlü insan faaliyetinin merkezinde konumlanmayı bir şekilde başarmış olan sosyal medya, farklı disiplinlerce ve çeşitli bağlamlardan incelenmekte ve ele alınmaktadır. Diğger iletişim araçları ile karşılaştırıldığında keşfedilmesi/ortaya çıkmasıyla kitleler arasında yaygınlaşma hızı açısından oldukça farklılaşan sosyal medya mecralarının dinamik yapıları, yapılan akademik çalısmaların da sürekliliğini gerekli kılmaktadır. Dolayısıyla bu mecralara ilişkin yapılan çalışmalar, güncel farklılıkları keşfetmek amacıyla çeşitli bağlamlardan yapilmakta ve araştırmalar sürekli bir şekilde devam etmektedir (Lee ve Ma, 2012; Chen, Sun, Wu ve Song, 2019; Gabore ve Xiujun, 2018; Palekar ve Sedera, 2018; Yaşar, 2020).

Başta gençler olmak üzere günümüz insanı açısından sosyal medya platformları hayatın merkezinde yer almaktadır (Kümpel, Karnowski ve Keyling, 2015, s. 1). Ticari faaliyetler, sağlık, e-devlet ve diğger resmi uygulamalar ve eğitim vb. her türlü insan faaliyeti bir şekilde internet ve sosyal medyayla ilişkilenmektedir. Örneğin, toptan veya perakende olsun, ticari faaliyetlerin azımsanmayacak bir kısmının internet ve buna bağlı sosyal medya uygulamaları üzerinden gerçekleştiği görülmektedir (Kim, Namkoong ve Chen, 2020, s. 1). İktisadi faaliyetler ister bireysel ister kitlesel hareketlilik açısından değerlendirilsin, ağın bu noktadaki etkisi geleneksel anlamdaki ekonomi ilişkilerinin yapısını değiştirecek kadar önemli sonuçları ortaya çıkartmaktadır. Bu değişim ve dönüşüm reklamdan, pazarlamaya, ünlü tanımlamasından, ihtiyaçların biçimlenmesine hatta ürün ve hizmetin üretim bandına girmeden şekillenmesine kadar tüm üretim, dağıtım ve tüketim ilişkisini yeniden biçimlendirmiştir (Başlar, 2013, s. 779-780).

Sosyal medya platformlarının çift yönlü ve etkileşimli olmaları ile anlık (real-time) iletişime olanak sunması gibi özellikleri iletişimin mekân ve zamandan büyük ölçüde bağımsız bir noktaya ulaşmasını sağlamıştır (Van Dijk, 2018, s. 12-17). İletişim etkisi, online-offline olarak iç içe geçmiş ve böylece her türlü içerik yeniden dolaşıma girerek güncelliğini koruma potansiyeline erişmiş̧ir. Bu noktada mobil internet ve bunu işlevsel kilan yeni nesil cep telefonları başta olmak üzere tablet vb. akıllı cihazların ulaştı̆̆ teknolojinin rolünü de göz önünde bulundurmak gerekir. Mobil internet, akılll mobil cihazlar ve bu ikisinin birlikteliğiyle kullanılan aplikasyonlar, günümüz insanını her zaman ve her yerden ağa dâhil ederek onu diğerleri açısından ulaşılabilir kılmaktadır.

Sosyal medyayı bu denli önemli kilan unsurların başında onun sıradan insanları bile birer kitle yayıncısına dönüştürebilme potansiyelinin olduğu düşünülmektedir (Segado-Boj, Diaz-Campo ve Redondo, 2019, s. 92). Öte yandan, önceden memnuniyetsiz bir müşteri veya seçmen iliş̧kisi kendi içinde kısıtlı bir toplumun konusu olurken sosyal medya bunu büyük kalabalıkların meselesi haline getirmeyi başarmışırı (Calhoun, 2013, s. 13). Geleneksel medyanın devasa organizasyonları ve yayın politikaları, sıradan insanların kısıtlı zamanlarını bireysel bir soruna çevirmeye pek elverişli bir ortam sunmamaktadır. Üstelik bu kısmen sağlansa bile günlük bazda yaşanan sınırsız olay döngüsü televizyon başta olmak üzere diğer kitle iletişim araçlarının yansıtma potansiyellerini aşmaktadır. Ancak, sosyal medya platformları sıradan insanların kişisel birer yayın mecrası olarak insanların birbirlerini takip edip çeşitli sorun ve durumlar karşısında kendilerini özdeşleştirerek, empati hatta sempati kurarak kolektif tepkiler verebildikleri interaktif ortamlardır (Lee ve Ma, 2012, s. 332). Böylece sıradan görünen bir memnuniyetsizlik, kötü bir müşteri ilişkisi, ürün veya hizmete ilişkin olumsuz bir deneyim gibi durumlar ağda kısa sürede büyüyerek kartopu etkisi oluşturma ve başa çıkılması imkânsız bir krize dönüşebilme potansiyeli taşımaktadır (Ürkmez, 2020, s. 121-122). Söz konusu bu unsurlar, sosyal medyanın potansiyelinden kaynaklanan çıtılardır.

Dijital teknoloji ve buna bağlı olarak sosyal medya platformlarının manipülasyona açık yapısı başta olmak üzere birtakım eleştiriler söz konusu olsa da sonuçta sosyal medyanın bahse konu etkisi ve gücü göz ardı edilmemelidir. Zira sosyal medyanın bireyleri örgütleme gücü, haberlerin çok hızlı yayılması ve kontrol edilmesinin neredeyse imkânsız olması, kurum ve yapıları tedirgin eden ve onların sıradan insanlara kulak vermelerini sağlayan unsurlar arasındadır (Castells, 2005). Artık günümüz bireyi hem haberi alan hem de haberi dağıtandır. Dolayısıyla sosyal medyayı haber edinme ve haber paylaşma amaçlı kullanan bireylerin yakından incelenmesi ihtiyacı ortaya çıkmaktadır. Bu çalışmada "We Are Social" ve "Hotsuite" tarafindan 2020 yll itibariyle yapılan bir araştırmada ortaya koyulan, Türkiye'de en çok kullanılan 5 (beş) sosyal medya platformunun (Instagram, Facebook, Twitter, YouTube ve Whatsapp), bireyler tarafindan haber edinme ve paylaşma amaçlı kullanımları ele alınmıştır. Bu çerçevede sosyal medyayı haber edinme amaçlı kullanan bireylerin, hangi sosyal medya platformundan ne skklikta haber edindiklerinin belirlenmesi, söz konusu bu sıklıklara göre daha detaylı incelenebilmeleri için kümelendirilmeleri ve elde edilen bu kümelerin bireylerin 
demografik özellikleri ve haber paylaşma davranışları açısından irdelenmesi amaçlanmıştır. Günümüz bireyinin haber edinme amaçlı sosyal medya kullanım dinamiğini daha iyi anlayabilmek açısından onların sosyal medyadan hem haber edinmesine hem de haber paylaşmasına yönelik bir bakış açısı sağlamaya çalışan bu çalışma, konuyla ilgili araştırma yapmak isteyenlere de çeşitli ipuçları sunmaktadır. Çalışmanın ilk bölümünde bireylerin dijitalleşmenin etkisi ve sosyal medya sayesinde pasif izleyiciden aktif-katılımc1 yayıncılara dönüşmesi ele alınmış; takip eden başlıkta sosyal medyadan haber edinme ve paylaşma konuları üzerinde durulmuştur. Son bölümde, yapılan ampirik araştırmanın bulguları analiz edilerek tartışılmış, devamında ise gelecek çalışmalara yön vermesi muhtemel önerilere yer verilmiştir.

\section{İlgili Literatür}

\section{Pasif İzleyicilerden Aktif Katılımcı Yayıncılara}

İletişim tarihi boyunca iletişim araç ve teknolojilerinde yaşanan her atıllım ve gelişmenin bilginin depolanması, yayılması ve kullanılması konusunda olumlu sonuçlar doğurduğu değerlendirilmektedir (Crowley ve Heyer, 2014, s. 18). Bu ilerleyiş elbette teknik düzeyde kalmamış sosyolojik yapı başta olmak üzere içinde insanın olduğu her türlü faaliyeti de bir şekilde etkilemiştir. Burada en önemli konu bilginin giderek daha geniş kitlelere yayılması ve insanların birbirinden haberdar olmasıly ilgilidir. Bilginin kitleler arasında yayılması, hemen her toplum için söz konusu olan seçkinci yaklaşımların giderek sarsılmasına neden olmuştur. Bilgi artık belli bir elit kitlenin tekelinde olmaktan çıkmış ve sıradan insanlar arasında yayılmaya başlamıştır. Bilgilenen kitleler giderek daha fazla sorgulamaya ve kendilerine sunulandan daha fazlasını veya farklısını talep etmeye başlamışlardır (Köseoğlu ve Al, 2013, s. 116-117). Bu yönüyle ele alındığında iletişim tarihi bir anlamda teknolojik ve ekonomik ilerlemelerden tutun demokratik hak ve hürriyetler ile yönetim biçimlerinin gelişmesine tüm insanlık tarihinin bir özeti olarak değerlendirilebilir.

Tüm kitle iletişim araçları olumsuz açılardan eleştirilere açı olmakla birlikte bireysel ve toplumsal bilgilenme ve aydınlanma noktasında önemli roller üstlenmişlerdir (Fukuyama, 2000). Kitle iletişim araçlarının en önemli işlevlerinden biri, toplumun birbirinden ve önemli olaylardan haberdar olmasının yanında farklı fikirlerin yayılmasına katkı sunarak tartışmalara ve böylece kolektif aklın oluşmasına katkı sunmasıdır. Böylece kitle iletişim araçları her konuda tartışmalara temel oluşturacak bilgi ve haberleri sunar, toplumsal aklın belirginleşmesine ve toplumun örgütlenmesine yardımcı olur. Ancak, televizyon başta olmak üzere, gazete, radyo, dergi gibi geleneksel kitle iletişim araçları günümüz sosyal medya uygulamalarından çok temel bir hususta ayrilır. Bu husus sosyal medya platformlarının çift yönlü ve interaktif bir yapıya sahip olmalarıdır (Bulunmaz, 2015, s. 331). Sosyal medyanın bu farkı, kitle iletişim araçları karşısında o güne kadar pasif ve edilgen olan bireyin aktif ve etken bir hüviyete kavuşmasına yol açmıstır.

Bireyin bahse konu dönüşümü elbette bir anda olmamış; bir sürecin sonunda olgunlaşarak ortaya çıkmıştır. Öyle ki internetin ilk dönemleri olan Web 1.0 altyapısı bilgiye erişim ve depolama konusunda devrimsel nitelikte yenilikler sunmakla birlikte günümüz dijital teknolojilerinin sunduğu altyapıdan oldukça uzaktır. Özetle bu ilk dönem bir internet sayfasına/sitesine sahip olmanın oldukça pahalı olduğu, yazılım ve uygulamaların oldukça sınırlı, bunları kullanmanın ise çoğu durumda uzmanlık gerektirdiği bir dönemdir (Karahasan, 2012, s. 72-74). İnternetin gelişip yaygınlaşması ile ă̆ kavramı ve olgusu giderek bireysel ve toplumsal hayatın merkezinde daha güçlü hissedilmeye başlanmıştır. Bu anlamda telefon ve tabletler gibi akıllı mobil cihaz teknolojileri ile yazılım alanındaki gelişmelerin rolü son derece önemlidir. Sonuç olarak tüm bu gelişmeler 2000'li ylllarla birlikte meyvesini vermiş, Web 2.0, Web 3.0 ve Web 4.0 gibi birçok teknolojinin ortaya çıkmasında/çıkartılmasında önemli bir rol oynamıştır. Bu gelişim silsilesi ile yakın gelecekte Web 5.0 gibi teknolojilerin konuşulması ve ortaya çıkması oldukça muhtemel görünmektedir. Sonuç olarak gelinen noktada birçok popüler sosyal medya uygulaması beşeri faaliyetlerin merkezinde yer almaktadır. Sosyal medya platformlarının atası sayılabilecek olan Facebook'un başarısının diğerleri için örnek teşkil etmesi, benzer uygulamaların geliştirilmesine adeta hız kazandırmıştır.

Sosyal medya platformlarının kullanıcı merkezli olduğu görülürken yine bu platformlarda içeriklerin kullanıcılar tarafından oluşturulduğu (kullanıcı türevli içerik) dikkat çekmektedir. Söz konusu platformların sunduğu olanaklar bireyler açısından kullanıcı denetimi, yetenekleri yansıtabilme, içerik üretimi ve paylaşımı, çift yönlü iletişim, yeni iş modelleri sunması gibi birçok farklı etkene dayanmaktadır. $\mathrm{Bu}$ bağlamda değerlendirildiğinde kullanıcı türevli içerik, etkileşim temelinde katılım esaslı olarak kullanıcıların mevcut bir içeriği yaratıcı bir şekilde değiştirebilmelerini ve bu tür içerikler üzerinde düzenleme yaparak yeni bir içerik veya doğrudan kendi özgün içeriklerini oluşturabilmelerini kapsamaktadır (Yavaşçalı ve 
Uğurhan, 2019, s. 650). Bununla birlikte, platformlarda dolaşıma giren içeriklerin genellikle anonim bir kimliğe sahip oldukları da değerlendirilmektedir (Lee ve Ma, 2012, s. 338; Chen vd., 2019, s. 3).

Sosyal medya platformları bir anlamda modern çağın agoraları olarak kabul edilebilir. Burası sıradan insanlar, seçkinler veya kurumların temsilcilerine kadar herkesin bir araya gelip dilediği şeyleri söyleyebildiği bir meydan gibidir. Antik Yunan'da olduğu gibi kentin yani insan faaliyetlerinin merkezinde yer alır, herkesin gözü bu meydana az çok ilişir ve kulakları bu meydanı bir şekilde dinler. Bir diğer deyişle, Facebook'la başladığı varsayılan sosyal medya platformlarının serüveni belki de McLuhan'ın global köyünün son yapıtaşları olarak değerlendirilebilir. Artık her şey açık ve herkes her şeyden haberdardır. Dolayısıyla enformasyonun geleneksel medya ile büyük oranda tekelleşmiş olan yapısı sosyal medyayla büyük ölçüde kırılmıştır. Hatta yeni medya teknolojileri içinde filizlenen sosyal medya bir anlamda geleneksel olanı dönüştürmeyi de başarmıştır (Lee ve Ma, 2012, s. 332). Böylelikle yakınsamayla birlikte her bir aracın tek bir araçta birleşmesi, insan makine/cihaz birlikteliği ve etkileşimini giderek daha üst seviyelere taşımıştır (Jenkins, 2006, s. 18; Neuman, 2018, s. 115-116).

Yaşanan bu gelişmelerle birlikte birey, mevcut ortamda yalnızca içerikleri tüketen değil, aynı zamanda üre-tüketici (prosumer) sıfattyla üreten bir konuma da sahip olmuştur (De Laguna-Alarcon, SierraHerrezuelo ve Rojas-de-Gracia, 2019, s. 252). Böylece sosyal medyanın keşfine/ortaya çıkmasına kadar diğer kitle iletişim araçlarıyla ilişkisinde pasif birer izleyici konumunda olan birey sosyal medyayla birlikte aktif-katılımcı birer yayıncıya dönüşmüştür (Yavaşçalı ve Uğurhan, 2019, s. 650). Sosyal medya platformları sayesinde birer kitle yayıncısına dönüşen birey bu mecraların sunmuş olduğu imkânları kullanarak kendisi veya çevresinde olan bitenlerle ilgili sosyal ağlarda paylaşımlarda bulunmaya başlamıştır (Yaşar, 2020, s. 31$32)$.

\section{Sosyal Medyadan Haber Edinme ve Paylaşma}

Sosyal medya platformları, insanları çeșitli konu ve ilgi alanlarına göre bir araya getiren mecralardır (Chen vd., 2019, s. 1-2). Çift yönlü ve etkileşimli yapıları sayesinde diğer kitle iletişim araçlarından ayrılan bu mecralar, kullanıcıları arasında yerel, bölgesel ve küresel anlamda iletişimi mümkün hâle getirir. Bu yönüyle sınırları ortadan kaldırmayı başararak küresel çapta herkesin her şeyden haberdar olmasını sağlar (Bulunmaz, 2015, s. 331). Günümüzde TV kanalları, gazeteler, dergiler vb. geleneksel kitle iletişim araçları da bu ağa dâhil olmuş durumdadır (Çakır, 2018, s. 543). Bu yapılar, gerek kurumsal olarak gerekse çalışanları aracilığıyla sosyal medya platformlarında varlık gösterirler. Geleneksel kitle iletişim araçları ile bunlara ait sosyal medya hesaplarının, bu mecraları belli ölçüde yönlendirmeyi ve gündem oluşturmayı başardıkları yadsınamaz (Gabore ve Xiujun, 2018, s. 23-24). Ancak, sosyal medya platformlarının temel bilgi kaynağının sıradan kullanıcılar olduğunu belirtmek gerekir. Diğer bir ifadeyle, sosyal medya platformlarında bilgi ve haberler çoğunlukla anonim bir şekilde oluşturulur (Lee ve Ma, 2012, s. 338; Chen vd., 2019, s. 3). Bununla birlikte, manipülasyona aç1k olması dolayısıyla sosyal medya platformlarının ne ölçüde anonim olduğu ve kendiliğinden oluştuğu her zaman tartışılmaktadır (Eren ve Aydın, 2014, s. 203; Babacan, 2014, s. 142). Fakat günün sonunda, sosyal medya platformlarının gördügü rağbet ile sıradan insanlar için bireysel yayıncılık yapabilmenin aracısı olduğu gerçeği değişmiş değildir.

Sosyal medya platformlarının -diğer kullanım amaçları bir yanda tutulmak üzere- çalışma kapsamında odaklanılan iki kullanım amacına hizmet ettiği değerlendirilmektedir (Lee ve Ma, 2012, s. 331). Bunlardan ilki bu mecraların kullanıcılar tarafindan haber edinme amaçlı olarak kullanımı, ikincisi ise bireyin çevresinde yaşanan ve haber değeri olduğunu düşündüğü olayları kitlelerle paylaşmasına aracılık etmesidir (Segado-Boj vd., 2019, s. 92). Haber edinme, kişilerin hemen her türlü olaydan farklı bakış açıları gözetilerek bilgilenmesini sağlarken fikir ve kanılarının oluşmasına yardımcı olur. Haber paylaşma ise bir anlamda kişilerin düşüncelerini özgürce açıklayabilmelerinin bir parçası olarak düşünülmektedir. Esasen bir haber, medya kanalları veya kişilerarası kanallar aracıllğıyla yayınlanan ya da gösterilen (özellikele önemli veya ilgi cekici) yeni etkinliklerin ve olayların güncel bir raporu olarak kabul edilir. Haberler, sosyal medyada online olarak paylaşılan diğer bilgilendirici içeriklerle (mesleki bilgi, kişisel bilgi, görseller, videolar ya da haber özelliği taşımayan günlük rutin paylaşımlar gibi) karșılaştırıldığında, zamanlama, doğruluk, nesnellik ve sosyal sorumluluk açısından çok daha değerlidir. Ayrıca, haber içerikleri kamuoyu, gündem belirleme ve toplumsal etkiler açısından sosyal medyada paylaşılan diğer bilgilendirici içeriklerden farklıdır. Dolayısıyla haber içerikleri, diğer bilgilendirici içeriklerden ayrılmaktadır. Zira burada haber değeri olan şey toplumu ilgilendiren yönü itibariyle bilgilendirme işlevini yerine getirerek kamuoyunun oluşmasına yardım etmektedir. İşte sosyal medya platformları, diğer kullanım amaçlarının yanında bu iki kullanım amacına da hizmet eden ortamlar olarak işlev görmektedir (Lee ve Ma, 2012, s. 332). 
Geleneksel medya olarak tanımlanan televizyon, gazete, radyo gibi kitle iletişim araçları insanların bilgilenme ve haberdar olma gibi ihtiyaçları konusunda büyük bir sorumluluk üstlenmişlerdir. Ancak, günümüz bireyleri bu ihtiyaçlarını yalnızca geleneksel araçlarla karşılamamaktadır. Bir diğer deyişle, geleneksel araçların tek başlarına bu ihtiyaçları karşılamada yeterli olmadıkları değerlendirilmektedir (Palekar ve Sedera, 2018, s. 1). Yapılan bazı çalışmalar da televizyon kanalları başta olmak üzere geleneksel medya araçlarına güvenin düşük olduğunu göstermektedir (Elvestad, Philips ve Feuerstein, 2018). Bu gibi sebeplerin altında medyadaki monopolleşmelerinde bir etkisi olduğu düşünülmektedir (Segado-Boj vd., 2019, s. 91-92). Öte yandan, sebepler ne olursa olsun ortaya çıkan sonuç, sosyal medya platformlarının burada oluşan boşluğu doldurmaya meyilli olduğu yönündedir.

Günümüzde sosyal medya platformları diğer işlevlerinin yanında haber medyası olarak da işlev görmektedir. Bireylerin sosyal medyadan haber edinme isteklerinin ise temelde iki yönünün bulunduğu değerlendirilmektedir. Bunlardan ilki sosyal medyanın alternatif medya olarak kabul edilmesi; diğeri ise sosyal medyanın tamamlayıcı medya olarak işlev görmesidir (Aydoğan ve Kırık 2012; Yaşar, 2020; Nah, Namkoong, Record ve Van Stee, 2017). Sosyal medya üzerinden edindiği kimi bilgileri olay yerinden veya olayın içinden aktaran birilerinin bulunması, elde edilen bazı bilgilerin daha güvenilir kabul edilmesini sağlamaktadır (De-Laguno-Alarcon vd., 2019, s. 250). Bazı durumlarda yaşanan bir olayla ilgili olarak basın mensuplarının oraya intikali ve haber aktarımları gecikebilmektedir. Ancak, orada bulunan bireylerin sahip oldukları akıllı cihazlar ve mobil internet erişimleri sayesinde olaya dair bilgiler dakikalar içinde sosyal medyaya düşebilmektedir. Böylece sosyal medya bir yönüyle mevcut olana, alternatif olarak işlev görmektedir (Su, Liu ve McLeod, 2019, s. 201).

Bazı durumlarda bireyler, geleneksel mecralardan edindikleri bilgileri yetersiz bulabilmekte veya daha detaylı bilgi edinmek ve fazlasını öğrenebilmek amacıyla sosyal medya platformlarına başvurabilmektedir (Palekar ve Sedera, 2018, s. 2). Sosyal medyanın yapısından farklı olarak geleneksel medya hiyerarşik bir organizasyon yapısına sahiptir. Bunun yanında geleneksel medya sorumluluk ve özgürlük alanını belirleyen yerleşik bir mevzuat ve meslek örgütlerinin çizdiği birtakım ilke ve kurallara tabidir (Kara, 2013, s. 19-21). Bu basamaklı yapı ve editöryal süreç, bir haber kitlelere sunulurken onu yeniden biçimlendirebilmekte veya gündem olmasının önüne geçebilmektedir. Dolayısıyla yayınlanmıs ancak detayları merak uyandıran bir olay hakkında daha fazla bilgi edinmek için sosyal medya platformlarına bakılabilmektedir. Böylece sosyal medya belli oranda haber olmuş ancak toplumda merak uyandıran bir olayın detaylandırılmasında rol oynayabilmektedir. Bir olaya dair görüntü, ses ve video gibi kayıtların şiddet içerikli, ahlâka aykırı veya infial uyandıracak nitelikte olması nedeniyle geleneksel medyada yayınlanmamas1, ancak merak duygusu ile insanların bunlara sosyal medya üzerinden ulaşma çabası tamamlayıcı işlevini anlatması açısından örnek olarak verilebilir. Bunun yanında özellikle toplumsal olaylar ve sokak hareketleri söz konusu olduğunda gerek eylemciler gerekse diğerleri için sosyal medya geleneksel medyanın vermekten kaçındığı veya süzerek verdiği haberleri detaylandırmak için başvurulan bir mecra niteliğindedir. Sosyal medyanın bu işlevine dair birçok akademik çalş̧ma da söz konusudur (Ali ve Fahmy, 2013; Youmans ve York 2012; Bruns, Highfield ve Burgess, 2013).

Sonuç olarak sosyal medyada yer alan paylaşımların bir kısmının, bireylerin çevrelerinde olup biten ve haber değeri taşıdığını düşündükleri olayları diğerlerine duyurma çabalarının bir ürünü olduğunu belirtmek gerekir (Kümpel vd., 2015, s. 1-2). Sosyal medya uygulamaları özelliklerine bağlı olarak ses, metin, video gibi her türlü içeriğin paylaşılmasına olanak sunarken YouTube, Twitter, Facebook ve Instagram gibi birçok platformda canlı yayın yapabilmek de mümkündür (Casalo, Flavian ve Sanchez, 2020, s. 1). Kullanıcılar, önceden kaydettikleri içerikleri takipçileri ile paylaşabilirken bir olay veya konu hakkında canlı yayın yapabilmektedir. Bu noktada, internet altyapısı ile günümüz akıllı cihazlarının mevcut yazılım teknolojisi birleşince sosyal medyayı kullanabilme becerisine sahip çoğu kullanıcının potansiyel birer basın mensubuna dönüştüğü değerlendirilebilir (Thompson, Wang ve Daya, 2019, s. 1-2; Kim vd., 2020, s. 1).

Özetle, bireyler şahit oldukları trafik kazaları, terör eylemleri, intihar, hırsızlık, toplumsal olaylar vs. haber değeri olan her türlü olayı sahip oldukları sosyal medya hesaplarından farklı formatlarda paylaşabilmektedir. Dahası, bireyler kaydettikleri bu içerikleri basın kuruluşlarının giderek yaygınlaşan ihbar hatlarına (Whatsapp ibbar hattı vb.) yollayarak yurttaş haberciliği yapabilmekte, böylelikle ana akım medyayı etkileyerek haber yapım sürecinin bir parçası haline gelebilmektedir (Ünal, 2019, s. 42; Karaman ve Önder, 2017, s. 176-178). Günün sonunda sıradan bireyler haber yapım sürecinin bir parçası olabildikleri gibi bazı durumlarda yaptıkları haber dolayısıyla bir başka haberin bizzat öznesi de olabilmektedir (Salgado ve Bobba, 2019, s. 2258). 


\section{Yöntem}

Bu çalışmada nicel araştırma yöntemi kullanılmış ve kesitsel tarama modelinden faydalanılmıştır. Kesitsel tarama modeli, bir popülasyonun ya da popülasyondan alınan örneklemin o andaki eğilimlerini, tutumlarını ve görüşlerini nicel bir şekilde, olduğu gibi tanımlamayı sağlamaktadır (Creswell, 2014, s. 13). Kesitsel tarama modeli kullanılarak yapılan bu araştırmada, We Are Social ve Hootsuite tarafindan belirlenen ${ }^{3}$ Türkiye'de en çok kullanılan beş sosyal medya platformunun (YouTube, Instagram, Facebook, Twitter ve Whatsapp) bireyler tarafından haber edinme amaçlı kullanımları ve söz konusu bireylerin haber paylaşma davranışları incelenmek istenmiştir.

\section{Amaç ve Önem}

Türkiye'de 2020 yllı itibariyle en çok kullanılan beş sosyal medya platformunun (YouTube, Instagram, Facebook, Twitter ve Whatsapp) bireyler tarafindan haber amaçl kullanım sıklıklarının ve bireylerin haber paylaşma davranışlarının incelenmesi bu çalışmanın esas amacıdır. İnceleme yapilırken bireyler, bu platformları kullanım sıklıklarına göre kümelendirilmek istenmiştir. Böylelikle haber edinme amaçlı kullanım sıklı̆̆ ile bireylerin demografik özelliklerinin bir ilişkisi olup olmadığı ve bu sıklıklar açısından haber paylaşma davranışının anlamlı bir şekilde farklılaşıp farklılaşmadığının belirlenmesi amaçlanmıştır. Ayrıca demografik özellikler açısından da haber paylaşma davranışının farklılaşıp farklılaşmadığının tespiti yapılmak istenmiştir. Daha önceki yapılan çalısmalarda sosyal medyayı genelde ya da özelde haber edinme amaçlı kullanma (Palekar ve Sedera, 2018; Gabore ve Xiujun, 2018; Song, Zuniga ve Boomgaarden, 2020) ve sosyal medyada haber paylaşma (Lee ve Ma, 2012; Karnowski, Leonhard ve Kümpel, 2017; Swart, Peters ve Broersma, 2018; Thompson vd., 2019; Ünal, 2019; Karaman ve Önder, 2017) açısından değerlendirmeler söz konusu olsa da bu çalışma söz konusu iki olguyu yapılıış çalışmalardan farklı olarak bireylerin kullanım sıklıkları özelinde incelemektedir. Özellikle bireylerin haber edinme amaçlı kullanım sıklıklarına göre kümelendirilmesi ve kümelerin yine bireylerin demografik özellikleri açısından incelenmesi, bu bireylere yönelik mevcut profili çizer niteliktedir. Öte yandan, bu kümeler açısından haber paylaşma davranışının incelenmesi de iki olgu arasındaki ilişkiyi ortaya koyabilmesi açısından önemlidir. Zira her iki olgu hem kendi içlerinde birbirleriyle hem de kendi dışlarında demografik değişkenlerle karşılaştırılarak daha belirgin bir kanı oluşturulmak istenmiştir. Bu bağlamda aşağıdaki araştırma sorularına cevaplar aranmıştır:

- Bireylerin sosyal medya platformlarını haber edinme amaçlı kullanım sıklıklarının dağılımı nasildir?

- Bireyler sosyal medya platformlarını haber edinme amaçlı kullanım sıklıklarına göre nasıl kümelenmektedir?

- Bireylerin sosyal medya platformlarını haber edinme amaçlı kullanım kümeleri ile demografik değişkenler (cinsiyet, yaş, eğitim durumu, aylık gelir ve sosyal medyada günlük harcanan zaman) arasında anlamlı bir bağ/ilişki var mıdır?

- Bireylerin haber paylaşma davranışı, bireylerin sosyal medya platformlarını haber edinme amaçlı kullanım kümeleri açısından anlamlı bir biçimde farklılaşmakta mıdır?

- Bireylerin haber paylaşma davranışı, demografik değişkenler (cinsiyet, yaş, eğitim durumu, aylık gelir ve sosyal medyada günlük harcanan zaman) açısından anlamlı bir biçimde farklılaşmakta midir?

\section{Evren ve Örneklem}

Bu araştırma Türkiye'de 2020 yll itibariyle en çok kullanılan beş sosyal medya platformunun (YouTube, Instagram, Facebook, Twitter ve Whatsapp) haber edinme amaçlı kullanım sıklğı ve haber paylaşma davranışıyla ilgili olduğundan dolayı, çalışmanın evrenini söz konusu beş platformu kullanan bireyler oluşturmaktadır. Ancak, bu bireylerin tamamına ulaşmak imkânsız olduğundan ötürü örneklemeye gidilmiştir ve olasılıklı olmayan örnekleme yöntemlerinden amaca uygun örnekleme bu çalışmada kullanılmıştır. Amaca uygun örneklemede, araştırma amacına uygun olarak örnekleme seçilecek bireylerden sadece uygun ve ulaşılabilir olanların örnekleme eklenmesi söz konusudur. Özellikle zaman ve bütçe kısıtllıı̆ın olduğu araştırmalarda bu örnekleme yöntemi tercih edilebilmektedir (Gegez, 2010, s. 217). Bu bağlamda yapılandırılan anket formu 22 Şubat-26 Şubat 2020 tarihleri arasında sosyal medya kanalları

\footnotetext{
${ }^{3}$ https://www.slideshare.net/DataReportal/digital-2020-turkey-january-2020-v01 (Erişim Tarihi: 20 Şubat 2020)
} 
aracılı̆̆ıyla dolaşıma sokulmuştur. Çalışmaya gönüllü bir şekilde katılmayı beyan edenlerin, yukarıda bahsedilen sosyal medya platformların hepsini kullanmaları gerektiğinden dolayı ankette bir kontrol sorusu kullanılmış ve bu platformların hepsini kullanırım diyenlerin yanıtları araştırma kapsamında değerlendirilmiştir. Daha sonra katılımcılara, bu platformları haber edinme amaçlı kullanım sıklıkları ve haber paylaşma davranışlarına yönelik sorular sorulmuştur. Toplamda 414 katılımcıdan veri toplanmıştır.

\section{Veri Toplama Yöntemi ve Aracı}

Çalışmada kullanılan veriler birincil veri toplama yöntemlerinden biri olan anket tekniği ile elde edilmiştir. Söz konusu anket Google Forms üzerine yüklenmiştir. Türkiye'de 2020 yllı itibariyle en çok kullanilan sosyal medya platformların belirleyebilmek amaciyla We Are Social ve Hootsuite tarafindan yapilmış araştırma incelenmiştir. İnceleme sonucunda YouTube, Instagram, Facebook, Twitter ve Whatsapp platformlarının Türkiye özelinde en çok kullanılan sosyal medya platformları olduğu görülmüş̧ür. Bununla birlikte, ilgili araştırmada bu platformlar dışında Facebook Messenger, Pinterest, LinkedIn gibi platformlar yer alsa da söz konusu beş platform \% 60'dan fazla kullanım oranına sahip olduğundan ötürü araştırmacılar tarafindan tercih edilmiştir. Dolayısıyla en çok kullanılan sosyal medya platformları bu çalışmada beş platformla sınırlandırılmıştır. Katılımcıların bu platformları haber edinme amaçlı kullanım sıklıklarını 5'li derecelendirme seçeneği şeklinde (1 - Hiçbir Zaman; 5 - Her Zaman) doldurmaları istenmiştir.

Sosyal medyada haber paylaşma davramışı ölçümleyebilmek amacıyla daha önceki bir çalışmada kullanılan ölçüm aracından faydalanılmıştır (Lee ve Ma, 2012, s. 336). Söz konusu ölçüm aracına ait iki madde hem araştırmacılar hem de iletişim alanında çalışan uzmanlar tarafindan kapsam geçerliği yapılarak araştırma amacıyla bütünleşik olarak Türkçeye uyarlanmıştır (Cevremde gerçeklessen, haber değeri olan olaylar sosyal medyadan paylaşırm; Diğer kullanuclarm haber değeri olan paylaşımlarm sosyal medyada yeniden paylaşırm). Öte yandan, alan uzmanlarının tavsiyesi ve araştırmacıların tespitleri çerçevesinde bir madde de bu ölçeğe eklenmiştir (Çevremde gerçekleşen, haber değeri olan olaylar kaydedip yaymlanması için basın kuruluşlarmm sosyal medya ibbar hatlarnna (Whatsapp vb.) gönderirim). Toplamda üç madde halinde ve 5 'li derecelendirme seçeneği şeklinde (1 - Hiçbir Zaman; 5 - Her Zaman) son haline getirilen bu ölçek, yapılan bir pilot çalışmayla test edilmiş ve maddelerin anlaşıllırlığ kontrol edilmiştir.

Pilot çalışma neticesinde sosyal medyayı aktif olarak kullanmakta olduğunu beyan eden 55 kişiden toplanan yanıtlar bağlamında yapilan güvenirlik analizinde Cronbach's Alpha katsayısın ,75 olarak elde edilmesi ve madde-toplam korelasyon katsayılarının ,4’ün üzerinde olmasından dolayı ölçeğin güvenilir olduğu kanaatine varılmıştır (Kalayc1, 2017; Hair, Black, Babin ve Anderson, 2014). Daha sonra esas çalışma gerçekleştirilmiştir. Esas çalışmada ise katılımcıların haber paylaşma davranışları ölçümlenmeden önce, araştırmacılar tarafından katılımcıların normal içeriği (kullanıcı türevli içerik) ve haber içeriği arasındaki ayrımı anlayabilmeleri adına bir bilgilendirme metni yazılmıștır "Kişiler, çevrelerinde yaşanan ve baber değeri olduğgnu düsü̈ndükleri olaylara dair içerikleri (video, resim, metin ses vb.) sosyal medya hesaplarndan paylasarak başkalarna duyurabilmektedir. Bu içerikler, diğgr bilgilendirici içeriklerle (mesleki bilgi, kişisel bilgi, görseller, videolar ya

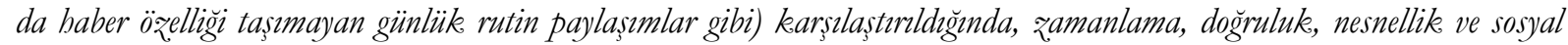
sorumluluk açısından bir değere sabiptir ve alternatif haber kaynağg olarak daha kelymetlidir”. Bu metni okuduktan sonra haber paylaşma davranışı ölçeğini doldurmaları istenmiştir.

\section{Veri Analizi ve Kullanılan Testler}

Verilerin temizlenmesinde ve derlenmesinde Microsoft Excel programı kullanılmıştır. Verilerin analizinde ise IBM SPSS 25 programından faydalanılmıştır. Kullanılan haber paylaşma davranışı ölçeğine yönelik geçerlik ve güvenirlik analizleri açımlayıcı faktör analizi ve Cronbach's Alpha katsayısının kontrolü ile sağlanmıştır. Bununla birlikte, araştırma sorularının cevaplanabilmesi adına frekans analizi, k-ortalamalar kümeleme analizi, ki-kare bağımsızlık testi, tek yönlü varyans analizi (ANOVA) ve bağımsız örneklemler ttest istatistiklerinden yararlanılmışır. Ulaşılan bulgular da tablolar yardımıyla açıklanmaya çalışılmışır.

\section{Bulgular}

Araştırma kapsamında 414 kişiden veri toplanmıştır. Toplanan veriye yapılan ön kontrol neticesinde 17 yanıtın uygunsuz bir şekilde doldurulduğu tespit edilmiş ve veri setinden çıkartılmasına karar verilmiştir. Sonra, sosyal medyada haber paylaşma davranışı ölçeğine yönelik tek değişkenli normallik sayıltısı kontrol edilmiş ve ölçeğin maddelerine ilişkin eğiklik ve basıklık değerleri incelenmiştir. Bu inceleme sonucunda maddelerin, önerilen mutlak değer olarak 2,2 eşik değer aralı̆̆nda $(-0,70 \sim 1,67)$ olduğu görülmüştür (Sposito, Hand ve Skarpness, 1983, s. 271). Bu bulguya ek kanit toplamak amaciyla Pallant (2011)'in 
önerdiği bir yaklaşım kullanılarak bu maddelerin etkili gözleme sahip olup olmadıkları değerlendirilmiştir. Değerlendirme sonucunda yalnızca bir maddenin toplamda 6 etkili gözleme sahip olduğu belirlenmiştir. Bu bağlamda ilgili maddenin ortalaması ve \% 5 kırpılmış ortalaması (etkili gözlemlerden) incelenerek ortalamalar arasındaki farkın çok düşük olduğu bulunmuştur $(0,1)$. Dolayısıyla tek değişkenli normalliğin bu çalışma kapsamında sağlandığı sonucuna ulaşılmıştır.

\section{Katılımcılara İlişkin Bulgular}

Çalışma katılımcılarının \% 39,8’i kadın ve \% 60,2’si erkektir. Katılımcıların yaşları çoğunlukla 23-32 yaș arasinda $(\% 40,6)$, daha az olarak ise 43 yaş ve üstünden $(\%$ 15,3) oluşmaktadır. Eğitim durumu açısından çoğunlukla lisans mezunlarının yer aldığı görülmektedir $(\% 47,9)$. Aylık gelir olarak katılımcıların çoğunlukla 2501-4500 TL arasında bir gelire sahip olduğu söylenebilir (\% 29,2). Katıllımcilar sosyal medyada günlük çoğunlukla 1-2 saat süre geçirmektedir (\% 40,3). Katıllımcıların haber edinme amaçlı en çok sıklıkta kullandıkları sosyal medya platformu Whatsapp'tır. Facebook platformu ise haber edinme amaçlı daha az sıklıkta kullanılmaktadır. Bu bilgiler Tablo 1'de paylaşılmıştır.

Tablo 1. Katılmonclarn Demografik Özellikeleri

\begin{tabular}{|c|c|c|c|}
\hline Değişken & Seçenekler & $n$ & $\%$ \\
\hline \multirow{2}{*}{ Cinsiyet } & Kadin & 158 & 39,8 \\
\hline & Erkek & 239 & 60,2 \\
\hline \multirow{4}{*}{ Yaş } & 22 yaş ve altı & 66 & 16,6 \\
\hline & $23-32$ aras 1 & 161 & 40,6 \\
\hline & $33-42$ aras 1 & 109 & 27,5 \\
\hline & 43 yaş ve üstü & 61 & 15,3 \\
\hline \multirow{4}{*}{ Eğitim Durumu } & Lise ve altı & 73 & 18,4 \\
\hline & Önlisans & 44 & 11,1 \\
\hline & Lisans & 190 & 47,9 \\
\hline & Lisansüstü & 90 & 22,6 \\
\hline \multirow{4}{*}{ Aylık Gelir } & 2500 TL ve altında & 111 & 28,0 \\
\hline & $2501-4500 \mathrm{TL}$ & 116 & 29,2 \\
\hline & 4501-6500 TL & 93 & 23,4 \\
\hline & $6501 \mathrm{TL}$ ve üstünde & 77 & 19,4 \\
\hline \multirow{4}{*}{$\begin{array}{l}\text { Sosyal Medyada Geçirilen Günlük } \\
\text { Zaman }\end{array}$} & 1 saatten az & 61 & 15,4 \\
\hline & 1-2 saat aras 1 & 160 & 40,3 \\
\hline & 3-4 saat aras 1 & 114 & 28,7 \\
\hline & 5 saat ve üstünde & 62 & 15,6 \\
\hline \multicolumn{2}{|l|}{ Toplam } & 397 & 100,0 \\
\hline \multirow{6}{*}{$\begin{array}{l}\text { Haber Edinme Amaçlı Sosyal } \\
\text { Medya Kullanım S1klığ1* }\end{array}$} & Platform & $O$ & $\boldsymbol{S}$ \\
\hline & Instagram & 2,53 & 1,37 \\
\hline & Facebook & 2,12 & 1,26 \\
\hline & Twitter & 2,65 & 1,62 \\
\hline & YouTube & 2,61 & 1,26 \\
\hline & Whatsapp & 3,23 & 1,40 \\
\hline
\end{tabular}

\section{Sosyal Medyada Haber Paylaşma Davranışına İlişkin Bulgular}

Araştırmada kullanılan haber paylaşma davranışı ölçeğine, çalışma örnekleminde faktörsel olarak nasıl bir dağılım gösterdiğini görebilmek amacıyla açımlayıcı faktör analizi (AFA) yapılmışır (temel bileşenler analiz̨i/varimax). Yapılan AFA sonucunda tek faktör olarak elde edilen yapıya yönelik KMO değerinin ,78 olduğu ve Barlett Küresellik Testi'nin ise anlamlı olduğu görülmüştür $\left(x^{2}: 322,857 ; s d: 3 ; p<, 001\right)$. Ayrıca açıklanan varyansın \% 65,75 ve öz değerin 1,97 olduğu da belirlenmiştir. Bu sonuçlar AFA'nın yorumlanması adına yeterli düzeyde kanıtları sağlamıştır (Hair vd., 2014, s. 102).

Haber paylaşma ölçeğinin maddelerine yönelik faktör yüklerinin ,722-,902 arasında dağı̆lım gösterdiği görülmektedir. Ayrıca ölçeğe yönelik yapılan güvenirlik analizi neticesinde Cronbach's $\alpha$ katsayısının ,74 düzeyinde olduğu tespit edildiği için ölçeğin güvenilir olduğu belirtilebilir (Kalayc1, 2017, s. 405). Öte yandan, ölçekte en yüksek ortalamaya sahip maddenin "diğer kullancolarn haber değeri olan paylaşımlarmı sosyal medyada yeniden paylaşırm" olduğu ve ölçeğin aritmetik ortalamasının 2,09 (S: 0,90) olduğu dikkat çekmektedir. Bu bulgular Tablo 2'de gösterilmiştir. 
Tablo 2. Haber Paylassma Davramış Ölçeğine Yönelik. AFA ve Güvenirlik. Analiz̧i Sonuçlar ile Betimsel İstatistikler

\begin{tabular}{|c|c|c|c|c|c|c|}
\hline Ölçek ve Madde & $A O$ & $S$ & $F \boldsymbol{Y}$ & $A T V$ & $\ddot{O D}$ & $C A$ \\
\hline Haber Paylaşma Davranışı & 2,09 & 0,90 & $x$ & & & \\
\hline $\begin{array}{l}\text { Çevremde gerçekleșen, haber değeri olan olayları sosyal } \\
\text { medyadan paylașırım }\end{array}$ & 2,27 & 1,16 & ,902 & & & \\
\hline $\begin{array}{l}\text { Diğer kullanıcıların haber değeri olan paylaşımlarını sosyal } \\
\text { medyada yeniden paylaşırım. }\end{array}$ & 2,32 & 1,12 & ,799 & 65,75 & 1,97 &, 74 \\
\hline $\begin{array}{l}\text { Çevremde gerçekleşen, haber değeri olan olayları kaydedip } \\
\text { yayınlanması için basın kuruluşlarının sosyal medya ihbar } \\
\text { hatlarına (Whatsapp vb.) gönderirim. }\end{array}$ & 1,69 & 1,06 & ,722 & & & \\
\hline
\end{tabular}

FY=Faktör Yükü; ATV=Açılanan Toplam Varyans; ÖD=Öz Değer; CA= Cronbach’s Alpha.

\section{Kümeleme Analizine İlişkin Bulgular}

Haber edinme amaçlı sosyal medya kullanım sıklığı açısından katılımcıları gruplandırabilmek için iki yaklaşımlı bir kümeleme analizine gidilmiştir. Bu yaklaşımdaki ilk aşamada, düzeylere ilişkin kümeleme yapılmadan önce hiyerarşik kümeleme yöntemlerinden Ward tekniği uygulanarak katılımcıların kullanım sıklıkları açısından nasıl bir örüntüye sahip olduklarına bakılmış ve burada sınıflandırma yapabilmek için haber edinme amaçlı sosyal medya platformlarını kullanma sıklı̆̆ ortalamaları kullanılmıştır. Ward tekniği, uygun sayıda küme sayısını belirlenebilmesi için bir yı̆̆ışım tablosu oluşturmaktadır. Bu tabloda her bir kümeyi oluşturan özellikler açıklayıcı ve yorumlanması kolay olduğu için küme sayısının belirlenmesinde kullanılmaktadır (Hair vd., 2014, s. 442). Sonuç olarak yığışım tablosundaki bulgular haber edinme sıklı̆̆1 açısından üç gruplu kümenin uygun olacağını göstermiştir.

Yaklaşımın ikinci aşamasında hiyerarşik olmayan kümeleme yöntemi tekniklerinden k-ortalamalar tekniğinden faydalanılmış ve birinci aşamada uygun görülen üç gruplu sınıflandırmanın güvenirliği test edilmiştir. Bu analiz sonucunda hem Ward hem de k-ortalamalar tekniği için elde edilen ortalamaların birbirlerine yakın düzeylerde olduğu belirlenmiştir. Dolayısıyla haber edinme amaçlı sosyal medya kullanım sıklığ için a) düşük sıklıkta kullananlar, b) orta s1klıkta kullananlar ve c) yüksek s1klıkta kullananlar olmak üzere üç kümeden oluşan sınıflandırma yapılmıştır. Elde edilen kümelere ilişkin betimsel bilgiler Tablo 3’te paylaşılmıştır.

Tablo 3. Kümeleme Analizi Sonucu

\begin{tabular}{|c|c|c|c|c|c|c|c|}
\hline \multirow{3}{*}{ Sosyal Medya Platformlan } & & \multicolumn{6}{|c|}{ Kümeler } \\
\hline & & \multicolumn{2}{|c|}{$\begin{array}{c}\text { Düsüuk } \\
(n=128 ; \% 32,2)\end{array}$} & \multicolumn{2}{|c|}{$\begin{array}{c}\text { Orta } \\
(n=157 ; \% 39,5)\end{array}$} & \multicolumn{2}{|c|}{$\begin{array}{c}\text { Yüksek } \\
(n=112 ; \% 28,2)\end{array}$} \\
\hline & & $O$ & $S$ & $O$ & $S$ & $O$ & $S$ \\
\hline Instagram & & 1,94 & 1,11 & 2,24 & 1,21 & 3,62 & 1,24 \\
\hline Facebook & & 1,84 & 1,12 & 1,85 & 1,03 & 2,81 & 1,42 \\
\hline Twitter & & 1,13 & 0,36 & 4,24 & 0,74 & 2,15 & 1,40 \\
\hline YouTube & & 1,82 & 0,86 & 2,45 & 1,10 & 3,75 & 1,02 \\
\hline Whatsapp & & 2,50 & 1,22 & 2,90 & 1,30 & 4,54 & 0,67 \\
\hline & $\mathrm{AO}$ & 1,85 & 0,94 & 2,74 & 1,08 & 3,37 & 1,15 \\
\hline
\end{tabular}

(1 - Hiçbir Zaman; 5 - Her Zaman).

Haber edinme amaçlı sosyal medyayı düşük sıklıkta kullananların $(n=128)$ en çok Whatsapp'ı ve en az Twitter'ı kullandıkları görülmektedir. Orta sıklıkta kullananlar $(n=157)$ çoğunlukla Twitter'ı kullanırken Facebook'u daha az kullanmaktadır. Yüksek sıklıkta kullananlar ise $(n=112)$ Whatsapp'ı, YouTube'u ve Instagram'ı çoğunlukla kullanırken Twitter'1 daha az kullanmaktadır.

\section{Haber Edinme Amaçlı Sosyal Medya Kullanım Sıklığı Kümelerinin Demografik Değişkenler İle İlişkisi}

Haber edinme amaçlı sosyal medya kullanım sıklı̆̆1 (HASMKS) kümeleri ile cinsiyet, yaş, eğitim durumu, aylık gelir ve günlük sosyal medyada harcanan zaman değişkenleri arasındaki ilişkiyi/bağ1 inceleyebilmek amacıyla ki-kare bağımsızlık testi uygulanmıştır. Analiz sonuçları Tablo 4'te paylaşılmıştır. 


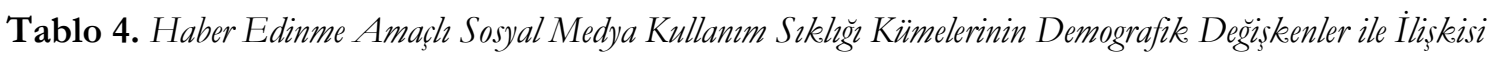

\begin{tabular}{|c|c|c|c|c|c|c|c|c|c|}
\hline \multicolumn{2}{|c|}{ Demografik Değişkenler } & \multicolumn{6}{|c|}{ Küme } & \multirow{3}{*}{$x^{2}(s d)$} & \multirow{3}{*}{$p$} \\
\hline \multirow{2}{*}{ Değişken } & \multirow{2}{*}{ Grup } & \multicolumn{2}{|c|}{ Düşük } & \multicolumn{2}{|c|}{ Orta } & \multicolumn{2}{|c|}{ Yüksek } & & \\
\hline & & $n$ & $\%$ & $n$ & $\%$ & $n$ & $\%$ & & \\
\hline \multirow{3}{*}{ Cinsiyet } & Kadın & 56 & 43,8 & 52 & 33,1 & 50 & 44,6 & \multirow{3}{*}{$4,83(2)$} & \multirow{3}{*}{,09 } \\
\hline & Erkek & 72 & 56,3 & 105 & 66,9 & 62 & 55,4 & & \\
\hline & Toplam & 128 & 100,0 & 157 & 100,0 & 112 & 100,0 & & \\
\hline \multirow{5}{*}{ Yaş } & 22 yaș ve altı & 19 & 14,8 & 29 & 18,5 & 18 & 16,1 & \multirow{5}{*}{$\begin{array}{c}18,61 \\
(6)\end{array}$} & \multirow{5}{*}{, $005^{* *}$} \\
\hline & $23-32$ aras1 & 37 & 28,9 & 72 & 45,9 & 52 & 46,4 & & \\
\hline & $33-42$ aras1 & 41 & 32,1 & 37 & 23,6 & 31 & 27,7 & & \\
\hline & 43 yaş ve üstü & 31 & 24,2 & 19 & 12,0 & 11 & 9,8 & & \\
\hline & Toplam & 128 & 100,0 & 157 & 100,0 & 112 & 100,0 & & \\
\hline \multirow{5}{*}{ Eğitim Durumu } & Lise ve alt1 & 34 & 26,6 & 10 & 6,4 & 29 & 25,9 & \multirow{5}{*}{$\begin{array}{c}44,68 \\
(6)\end{array}$} & \multirow{5}{*}{$<, 001$} \\
\hline & Önlisans & 23 & 18,0 & 9 & 5,7 & 12 & 10,7 & & \\
\hline & Lisans & 51 & 39,8 & 87 & 55,4 & 52 & 46,4 & & \\
\hline & Lisansüstü & 20 & 15,6 & 51 & 32,5 & 19 & 17,0 & & \\
\hline & Toplam & 128 & 100,0 & 157 & 100,0 & 112 & 100,0 & & \\
\hline \multirow{5}{*}{ Aylık Gelir } & $2500 \mathrm{TL}$ ve alt1 & 31 & 24,2 & 43 & 27,4 & 37 & 33,0 & \multirow{5}{*}{$\begin{array}{c}13,28 \\
(6)\end{array}$} & \multirow{5}{*}{,04* } \\
\hline & 2501 TL-4500 TL & 42 & 32,8 & 38 & 24,2 & 36 & 32,2 & & \\
\hline & 4501 TL-6500 TL & 23 & 18,0 & 43 & 27,4 & 27 & 24,1 & & \\
\hline & 6501 TL ve üstü & 32 & 25,0 & 33 & 21,0 & 12 & 10,7 & & \\
\hline & Toplam & 128 & 100,0 & 157 & 100,0 & 112 & 100,0 & & \\
\hline \multirow{5}{*}{$\begin{array}{l}\text { Sosyal Medyada } \\
\text { Günlük } \\
\text { Harcanan } \\
\text { Zaman }\end{array}$} & 1 saatten az & 39 & 30,5 & 8 & 5,1 & 14 & 12,5 & \multirow{5}{*}{$\begin{array}{c}76,58 \\
(6)\end{array}$} & \multirow{5}{*}{$<, 001$} \\
\hline & $1-2$ saat aras 1 & 69 & 53,9 & 54 & 34,4 & 37 & 33,0 & & \\
\hline & 3-4 saat aras 1 & 13 & 10,2 & 65 & 41,4 & 36 & 32,2 & & \\
\hline & 5 saat ve üstü & 7 & 5,4 & 30 & 19,1 & 25 & 22,3 & & \\
\hline & Toplam & 128 & 100,0 & 157 & 100,0 & 112 & 100,0 & & \\
\hline
\end{tabular}

${ }^{* *} p<, 01 ; * p<, 05$.

HASMKS kümeleri ile cinsiyet $\left(x^{2}=4,83 ; s d=2 ; p>, 05\right)$ arasında anlamlı bir ilişki/bağ tespit edilememiştir. Bununla birlikte, HASMKS kümeleri ile yaş $\left(x^{2}=18,61\right.$; sd $\left.=6 ; p<, 01\right)$, eğitim durumu $\left(x^{2}\right.$ $=44,68 ; s d=6 ; p<, 001)$, aylık gelir $\left(x^{2}=13,28 ; s d=6 ; p<, 05\right)$ ve sosyal medyada günlük harcanan zaman $\left(x^{2}=76,58 ; s d=6 ; p<, 001\right)$ değişkenleri arasında anlamlı bir ilişki/bağ olduğu görülmüştür.

Tespit edilen bu anlamlı ilişkilere/bağlara yakından bakıldığında, HASMKS düşük olanların çoğunlukla 33-42 yaş aralığından oluştuğu (\% 32,1), orta (\% 45,9) ve yüksek olanların (\% 46,4) ise 23-32 yaş aralığında yer aldığı görülmektedir. Eğitim durumu açısından bütün HASMKS kümelerinin ağırlıklı olarak lisans mezunlarından oluştuğu dikkat çekmektedir. Ancak, bu durum lisans mezunlarının araştırma örnekleminde çoğunlukta olmasından kaynaklanabilir. Öte yandan, HASMKS düşük olan katılımcıların ikinci olarak lise ve altı eğitim düzeyinden mezun olanlardan oluştuğu söylenebilirken $(\% 26,6)$, orta olanların ikinci olarak lisansüstü mezunlarından (\% 32,5) ve yüksek olanların ikinci olarak lise ve altından $(\%$ 25,9) oluştuğu ifade edilebilir. Düşük olanlar, ağırlıklı olarak 2501 TL ve 4500 TL aralığında aylık gelire sahipken (\% 24,2), orta olanlar çoğunlukla 2500 TL ve altı ile 4501 TL-6500 TL arasında aylık geliri olanlardan $(\%$ 27,4) oluşmaktadır. Son olarak, sosyal medyada günlük harcanan zaman açısından HASMKS düşük (\% 53,9) ve yüksek olanların (\% 33) ağırlıklı olarak günlük 1-2 saat arasında ve orta olanların 3-4 saat arasında (\% 41,4) günlük zaman harcadıkları görülmektedir. Bununla birlikte, cinsiyet açısından anlamlı bir ilişkinin/bağın bulunamaması cinsiyet fark etmeksizin katılımcıların haber edinme amaçlı sosyal medya medyayı benzer sıklıklarda kullandığını gösterir niteliktedir.

\section{Haber Paylaşma Davranışının Haber Edinme Amaçı Sosyal Medya Kullanım Sıklığı Kümeleri Açısından İncelenmesi}

HASMKS açısından sosyal medyada haber paylaşma davranışının istatistiksel olarak anlamlı bir şekilde farklılaşıp farklılaşmadığını tespit edebilmek amacıyla tek yönlü varyans analizi (ANOVA) gerçekleştirilmiştir. Analiz sonucunda Levene istatistiği, haber paylaşma davranışı açısından HASMKS kümelerinin $(F=10,045 ; p<, 001)$ homojen dağılmadığını gösterdiği için analizin yorumlanması aşamasında Brown-Forsythe istatistiği kullanılmıştır (Pallant, 2011, s. 253). Elde edilen sonuçlar Tablo 5'te paylaşılmıştır. 
Tablo 5. HASMKS Açısından Haber Paylaşma Davranışmm İncelenmesi

\begin{tabular}{clccclcccc}
\hline Değişken & \multicolumn{1}{c}{$\boldsymbol{G r u p}$} & $\boldsymbol{n}$ & $\boldsymbol{A O}$ & $\boldsymbol{S}$ & $\boldsymbol{K} \boldsymbol{T}$ & $\boldsymbol{s d}$ & $\boldsymbol{F}$ & $\boldsymbol{p}$ & Tamhane \\
\hline Haber & (1) Düşük & 128 & 1,81 & 0,74 & Gruplar Arası & 2 & & & $1-2$ \\
Paylaşma & (2) Orta & 157 & 2,07 & 0,89 & Grup Içi & 394 & 16,620 & $<, 001$ & $1-3$ \\
Davranış1 & (3) Yüksek & 112 & 2,46 & 0,96 & Toplam & 396 & & & $2-3$ \\
\hline
\end{tabular}

(1 - Hiç; 5 - Her Zaman)

Tablo 5'te HASMKS açısından haber paylaşma davranışının anlamlı bir şekilde farklılaştı̆̆ görülmektedir $(F=16,620 ; p<, 001)$. Elde edilen bu farkl1lı̆ın hangi düzey grupları arasında olduğunu belirleyebilmek için Tamhane testi uygulanmıştır (Kalayc1, 2017, s. 15). Test sonuçlarına göre HASMKS düşük olanlar ile orta ( $\mathrm{md}=-0,25 ; p<, 05)$ ve yüksek ( $\mathrm{md}=-0,64 ; p<, 001)$ olanlar arasında anlamlı bir farklilık vardır. HASMKS orta olanlar ile yüksek olanlar arasında anlamlı bir farklılık söz konusudur (md = $-0,39 ; p<, 01)$. Dolayısıyla, HASMKS orta olanlar, düşük olanlara göre daha fazla; yüksek olanlar ise düşük ve orta olanlara göre daha fazla sosyal medyada haber paylaşma davranışını gerçekleştirmektedir.

\section{Demografik Değişkenler Açısından Haber Paylaşma Davranışının İncelenmesi}

Cinsiyet, yaş, eğitim durumu, aylık gelir ve sosyal medyada günlük harcanan zaman değişkenleri açısından haber paylaşma davranışının anlamlı bir şekilde farklılaşıp farklılaşmadığını tespit edebilmek amacıyla bağımsız örneklemler t-test ve tek yönlü varyans analizi (ANOVA) kullanılmıştır. Elde edilen sonuçlar Tablo 6 ve Tablo 7'de gösterilmiştir.

Tablo 6. Cinsiyet Açsından Haber Paylaşma Davramışının İncelenmesi

\begin{tabular}{|c|c|c|c|c|c|c|c|c|c|}
\hline \multirow{2}{*}{ Değişken } & \multirow{2}{*}{ Cinsiyet } & \multirow{2}{*}{$n$} & \multirow{2}{*}{$A O$} & \multirow{2}{*}{$S$} & \multicolumn{2}{|c|}{ Levene Testi } & \multirow{2}{*}{$t$} & \multirow{2}{*}{$s d$} & \multirow[b]{2}{*}{$p$} \\
\hline & & & & & $F$ & $p$ & & & \\
\hline \multirow{2}{*}{$\begin{array}{c}\text { Haber Paylaşma } \\
\text { Davranışı }\end{array}$} & Kadın & 158 & 2,14 & 0,94 & \multirow{2}{*}{1,299} & \multirow{2}{*}{,255 } & \multirow{2}{*}{0,894} & \multirow{2}{*}{395} & \multirow{2}{*}{,372 } \\
\hline & Erkek & 239 & 2,06 & 0,88 & & & & & \\
\hline
\end{tabular}

Tablo 7. Yass, Eğitim Durumu, Aylık Gelir ve Sosyal Medyada Günlük Harcanan Zaman Açısından Haber Paylaşma Davramisinin Incelenmesi

\begin{tabular}{|c|c|c|c|c|c|c|c|c|c|}
\hline $\begin{array}{c}\text { Demografik } \\
\text { Değişken }\end{array}$ & Grup & $n$ & $A O$ & $\boldsymbol{S}$ & $K T$ & $s d$ & $F$ & $p$ & Bonferroni \\
\hline \multirow{4}{*}{ Yaş } & 22 yaş ve altı & 66 & 2,11 & 1,01 & & & \multirow{4}{*}{0,946} & \multirow{4}{*}{,418 } & \multirow{4}{*}{-} \\
\hline & $23-32$ aras 1 & 161 & 2,06 & 0,91 & Gruplar Aras1 & 3 & & & \\
\hline & $33-42$ aras 1 & 109 & 2,05 & 0,78 & Grup İçi & 393 & & & \\
\hline & 43 yaş ve üstü & 61 & 2,27 & 0,97 & Toplam & 396 & & & \\
\hline \multirow{4}{*}{$\begin{array}{l}\text { Eğitim } \\
\text { Durumu }\end{array}$} & Lise ve alt1 & 73 & 2,04 & 0,82 & & & \multirow{4}{*}{0,284} & \multirow{4}{*}{837} & \multirow{4}{*}{-} \\
\hline & Önlisans & 44 & 2,06 & 0,96 & Gruplar Aras1 & 3 & & & \\
\hline & Lisans & 190 & 2,14 & 0,95 & Grup İçi & 393 & & & \\
\hline & Lisansüstü & 90 & 2,07 & 0,85 & Toplam & 396 & & & \\
\hline \multirow{4}{*}{ Aylik Gelir } & 2500 TL ve altı & 111 & 2,04 & 0,87 & Gruplar A res & 3 & \multirow{4}{*}{0,331} & \multirow{4}{*}{,803 } & \multirow{4}{*}{ - } \\
\hline & $2501-4500 \mathrm{TL}$ & 116 & 2,09 & 0,95 & & & & & \\
\hline & 4501-6500 TL & 93 & 2,16 & 0,91 & Grup İçi & 393 & & & \\
\hline & 6501 TL ve üstü & 77 & 2,12 & 0,89 & Toplam & 396 & & & \\
\hline \multirow{4}{*}{$\begin{array}{l}\text { Sosyal } \\
\text { Medyada } \\
\text { Günlük } \\
\text { Harcanan } \\
\text { Zaman }\end{array}$} & (1) 1 saatten az & 61 & 1,75 & 0,77 & & & \multirow{4}{*}{9,193} & \multirow{4}{*}{$<, 001$} & \multirow{4}{*}{$\begin{array}{l}1-3 \\
1-4 \\
2-4 \\
3-4\end{array}$} \\
\hline & (2) $1-2$ saat aras 1 & 160 & 2,01 & 0,76 & Gruplar Aras1 & 3 & & & \\
\hline & (3) 3-4 saat aras 1 & 114 & 2,15 & 0,86 & Grup İçi & 393 & & & \\
\hline & $\begin{array}{l}\text { (4) } 5 \text { saat ve } \\
\text { üstünde }\end{array}$ & 62 & 2,54 & 1,21 & Toplam & 396 & & & \\
\hline
\end{tabular}

(1-Hic;; 5-Her Zaman).

Tablo 6'da görüleceği üzere cinsiyet açısından haber paylaşma davranışı anlamlı bir şekilde farklılaşmamaktadır. Bu bağlamda, cinsiyet fark etmeksizin sosyal medyada haber paylaşma davranışının benzer düzeylerde gerçekleştirildiği ifade edilebilir. Tablo 7'de haber paylaşma davranışının sosyal medyada günlük harcanan zaman açısından anlamlı bir şekilde farklılaştı̆̆ $(F=9,193 ; p<, 001)$; yaş, eğitim durumu ve aylık gelir açısından farklılaşmadığı görülmektedir $(p>, 05)$. Söz konusu bu farkllığın hangi gruplar arasında olduğunu tespit edebilmek amacıyla Bonferroni testi yapılmıştır. Test sonuçlarına göre günlük 1 saatten az zaman harcayanlar ile günlük $3-4$ saat $(\mathrm{md}=-0,40 ; p<, 05)$ ve günlük 5 saat ve üstünde $(\mathrm{md}=$ $0,79 ; p<, 001)$ zaman harcayanlar arasında anlamlı bir farklılık vardır. Günlük 1-2 saat zaman harcayanlar ile 
5 saat ve üstünde zaman harcayanlar arasında anlamlı bir farklılık vardır ( $m d=-0,52 ; p<, 001)$. Günlük 3-4 saat zaman harcayanlar ile günlük 5 saat ve üstünde zaman harcayanlar arasında anlamlı bir farklılık vardır (md $=-0,39 ; p<, 05$ ). Elde edilen bu sonuçlar kısaca özetlenirse sosyal medyada günlük daha fazla zaman harcayan katılımcıların daha çok sosyal medyada haber paylaşma davranışı gerçekleştirdiği, daha az süre harcayanların ise daha az paylaşım davranışı gerçekleştirdiği değerlendirilebilir. Öte yandan, yaş, eğitim durumu ve aylık gelir fark etmeksizin kullanıcıların benzer düzeylerde sosyal medyada haber paylaşma davranışı gerçekleştirdiği de söylenebilir.

\section{Sonuç ve Tartışma}

Bu çalışmada Türkiye'de 2020 yll itibariyle en çok kullanılan beş sosyal medya platformunun haber edinme amaçlı kullanım sıklıkları belirlenmeye ve bu sıklıklar üzerinden sosyal medyada haber paylaşma davranışı incelenmeye çalışılmıştır. Öte yandan, haber edinme amaçlı kullanım sıklığına göre katıllımcılar kümelere ayrilmış ve söz konusu kümelerin demografik değişkenlerle (cinsiyet, yaş, eğitim durumu, aylık gelir ve sosyal medyada günlük harcanan zaman) ilişkisine bakılarak bir profil ortaya koyulmak istenmiştir. Ayrıca haber paylaşma davranışı, demografik değişkenler açısından da değerlendirilerek mercek altına alınmaya çalışılmıştır.

Sosyal medya platformlarının bireysel ve toplumsal alandaki etkisi açısından çalışma bulguları önemli birtakım ipuçları sunmakta ve sosyal medya platformlarının günümüzde insan hayatı ve faaliyetleri açısından merkezi konumunu teyit etmektedir. Özellikle sosyal medyada günlük harcanan zaman, bireysel ve toplumsal yaşam ile günlük hayat içinde ne kadar önemli bir zaman dilimini kapladığını göstermesi açısından önemlidir. Genel olarak bakıldığında haber edinme amaçlı en sık kullanılan sosyal medya platformunun Whatsapp, en az kullanılanın ise Facebook olduğu görülmektedir. Bu da bireylerin Whatsapp'ı haber edinme amaçlı daha çok tercih ettiklerini göstermektedir. Özellikle Whatsapp'in sesli ve görüntülü görüşme, konum, metin, anında fotoğraf ve video paylaşım gibi niteliklere sahip olması haber edinme açısından bireylere kolaylıklar sağlamaktadır (Ünal, 2019, s. 34). Diğer taraftan, katıllımcılar genel olarak sosyal medya ihbar hatlarına haber değeri olan olayları daha az sıklıkta kaydedip göndermekte ve en çok sıklıkta diğer kullanıcılar tarafindan paylaşılan sosyal medyada haber değerine sahip içerikleri yeniden paylaşmaktadır. Benzer şekilde, haber değeri olan olayları da sosyal medya hesaplarından paylaşabilmektedir. Dolayısıyla, katılımcılar haber değeri olan olayları çoğunlukta kendi sosyal medya hesaplarından paylaşmayı tercih etmektedir. Sosyal medya ihbar hatlarına gönderme durumu ise biraz daha geri planda kalmaktadır. Bu durum, haber paylaşma bağlamında ihbar hatlarında medya kuruluşlarına aktarılan konuların nihayetinde belirli bir filtreye maruz kalması olabilir. Bir diğer deyişle, medya kuruluşlarının ekrana vermeyi tercih ettiği konuların kapsamına giremeyen haberlerin, yayınlanamamasıdır (Karaman ve Önder, 2017, s. 178).

Haber edinme amaçlı sosyal medya kullanım sıklığı düşük, orta ve yüksek sıklıkta kullanım olmak üzere üç kümeye ayrılmıştır. Kümelere göre bir değerlendirme yapıldığında düşük ve yüksek sıklıktakiler en fazla Whatsapp'1 ve en az Twitter's kullanmaktadır. Bununla birlikte, orta sıklıktakiler en fazla Twitter'1 ve en az Facebook'u kullanmaktadır. Twitter, sosyal medyayı haber edinme amaçlı orta sıklıkta kullananlar için daha çok tercih edilen bir sosyal ağdır. Whatsapp ise hem düşük hem de yüksek sıklıkta sosyal medyayı haber edinme amaçlı kullananların daha çok tercih ettikleri bir platformdur. Ancak, düşük sıklıktakiler çoğunlukla Whatsapp'ı kullanma eğiliminde olurken yüksek sıklıktakiler haber edinme amaçlı olarak Whatsapp'la birlikte YouTube, Instagram ve nispeten Facebook gibi sosyal ağları da kullanabilmektedir. Twitter'ın haber amaçlı kullanımı, bu platformun kendi mantığı içerisinde değerlendirildiğinde doğal bir sonuçtur. Whatsapp açısından ise durum irdelenmeye değerdir. Kapalı ve amaca uygun gruplar kurarak bunlar üzerinden haberleşmeye olanak sunan Whatsapp, içeriğin kişiselleştirilmesi noktasında diğer mecralardan daha hedefli bir ilişki biçimine olanak sunabilmektedir. Bu anlamda kısıtlı çalışmalar olmakla birlikte Whatsapp'ın bilgi ve haber paylaşımı bağlamında kişi ve gruplar arasında giderek daha fazla ön plana çıktı̆̆ düşünülmektedir (Karaman ve Önder, 2017; Ünal, 2019). Burada bilgi veya haberin bir kişi veya gruba göre özelleştirilebilmesi ya da bireyin tanıdıklarından gelebilmesi dolayısıyla daha güvenilir kabul edilmesi gibi faktörler söz konusu olabilir. Sonuç olarak sosyal medyanın haber edinme amaçlı kullanımı değerlendirildiğinde belli platformlar daha ön plana çıkmakla birlikte sosyal medya platformlarının geleneksel medyaya alternatif ve onu tamamlayan bir mecra olarak giderek daha belirginleştiği değerlendirilmektedir. 
Demografik değişkenler açısından sosyal medyanın haber edinme amaçlı kullanım sıklığı kümeleri değerlendirildiğinde, cinsiyet fark etmeksizin hem kadınların hem de erkeklerin benzer sıklıklarda sosyal medyayı haber edinme amaçlı kullandıkları görülmektedir. Bu bulgu Becan (2018, s. 250) tarafindan yapilan çalışmanın bulgularını bir adım daha ileriye taşımaktadır. Becan, çalısmasında sosyal medyada haber takip etme motivasyonlarının cinsiyet açısından farklılaşmadı̆̆ını tespit etmiştir. Bu çalışmada da haber edinme amacıyla kullanım sıklıklarının farklılaşmadığının tespiti, cinsiyetin söz konusu olgu üzerinde etkili bir role sahip olmadığını gösteriyor olabilir. Ancak yaş, eğitim durumu, aylık gelir ve sosyal medyada günlük harcanan zaman açısından sıklıklar değişim göstermektedir. Sosyal medyayı haber edinme amaçlı orta ve yüksek sıklikta kullananlar genellikle genç diye nitelendirilebilecek yaştakilerdir. Bununla birlikte, yaşça daha büyük olanlar genellikle sosyal medyayı haber edinme amaçlı düşük sıklıkta kullanmaktadır. Bu durum yaşça daha büyük olan bireylerin haber edinme amaçlı geleneksel medya mecralarını daha çok tercih ediyor olmalarını gösterebilir. Yaşça daha genç olanların ise daha fazla sosyal medya platformlarını kullanmaları göz önünde tutulduğunda (Özata, Kılıçer ve Ağlargöz, 2014, s. 20), elde edilen bu sonucun aslında haber edinme sıklığı açısından da benzer olabileceği söylenebilir. Zira sosyal medyada paylaşım yapma gibi davranışlar bu platformlara yönelik birtakım yeni medya okuryazarlığı becerilerini gerektirdiğinden ötürü ve genç neslin bu becerilere daha fazla sahip olduğu bilindiğinden dolayı (Uğurhan, Genç Kumtepe, Kumtepe ve Saykıl1, 2020, s. 144) sonucun böyle çıktı̆̆1 düşünülmektedir.

Eğitim durumu bağlamında, düşük sıklıktakiler genellikle lise ve altı ile önlisans programlarında eğitim derecelerine sahipken orta ve yüksek sıklıktakiler genellikle lisans ve lisansüstü düzeylerde eğitim derecesine sahiptir. Dolayısıyla, eğitim düzeyiyle birlikte haber edinme amaçlı sosyal medya kullanım sıklığının yükseldiği ifade edilebilir. Bir diğer deyişle, eğitim düzeyi yüksek olan kişilerin sosyal medyadan haber edinme sıklığı da yüksektir. Bu sonuç, Kılıç ve İspir (2020) tarafından yapilan çalışmayla benzer sonuçlar ortaya koymaktadır. Kılıç ve İspir (2020, s. 282)'e göre eğitim düzeyi yükseldikçe bireylerin bilgiye duydukları ihtiyaç artmaktadır. Özellikle eğitim düzeyi, bireyin çevresiyle olan iletişiminde yakın çevre ve dünyada olan olayları anlama ve analiz etmesinde belirleyici bir unsurdur. Eğitim düzeyi yükselen birey, çevresinde ve dünyada olup biten olaylar hakkında bilgilenmek amacıyla sosyal medya platformlarını daha sık kullanabilmektedir. Bununla birlikte, aylık gelir bağlamında sıklık sınırları tam olarak çizilemese de aylık geliri yüksek olanların orta ve yüksek sıklıkta sosyal medyayı haber edinme amaçlı kullandıkları ifade edilebilir. Aylık geliri nispeten düşük olanların, düşük ve orta sıklıkta sosyal medyayı haber edinme amaçlı kullandıkları görülmektedir.

Sosyal medyada günlük harcanan zaman bağlamında ise sosyal medyada günlük daha az süre geçirenlerin genellikle düşük sıklıkta haber edinme amaçlı sosyal medyayı kullandıkları görülürken, günlük daha fazla süre geçirenlerin orta ve yüksek sıklıkta haber edinme amaçlı kullanım sergiledikleri değerlendirilebilir. Burada günlük daha az süre geçirenlerin bu az süre içerisinde haber edinme yerine sosyalleşmek ya da eğlenmek gibi amaçlarla sosyal medyayı kullandıkları düşünülebilir. Zira sosyal medyayı daha az kullananların dışa dönük olma, bilgi ve etkileşim gibi motivasyonlarla bu platformları kullandıkları bilinmektedir (Erdoğan, Özata, Doğan ve Şaşmaz, 2017, s. 396).

Sosyal medyada haber paylaşma davranışı açısından bir değerlendirme yapıldığında, haber edinme amaçlı sosyal medyayı daha çok sıklıkta kullananlar daha az sıklıkta kullananlara göre daha fazla haber paylaşma davranışını gerçekleştirmektedir. Bu bağlamda daha sık kullananların bu platformlardan edindikleri haberler kapsamında daha fazla haber paylaşma davranışı gerçekleştirebilecekleri söylenebilir. Bununla birlikte, yalnızca bu platformlardan edinilen haberleri değil, günlük hayatta bireylerin şahit oldukları haberleri de sosyal medyadan paylaşabilecekleri belirtilmelidir. Burada demografik özellikler göz önünde tutulduğunda, cinsiyet, yaş, eğitim durumu ve aylık gelir fark etmeksizin sosyal medyada haber paylaşma davranışının benzer sıklıklarda gerçekleştirildiği ifade edilebilir. Bir diğer deyişle, bireyler hangi cinsiyetten, yaştan, eğitim durumundan ya da ne kadar aylik gelire sahip oldukları değişmeksizin haber paylaşma davranışını benzer sıklıklarda yapmaktadır. Bu durum ise haber paylaşma davranışının kısmen bu demografik değişkenler açısından benzer düzeylerde olduğunu göstermektedir. Ancak, söz konusu sosyal medyada günlük harcanan zaman olduğunda haber edinme sıklı̆gındaki bulguyla benzer olarak, daha fazla zaman geçirenlerin daha fazla haber paylaşma davranışı sergiledikleri görülmektedir. Yani, günlük daha fazla zaman geçirenler daha fazla haber paylaşmaya yatkın olmakta ve böylelikle daha fazla haber yayıncısına dönüşebilmektedir. 


\section{Sınırlılıklar ve İleri Çalışmalar}

Bu çalışma 2020 yılı itibariyle Türkiye'de en fazla kullanılan beş sosyal medya platformunu kullanan 397 katılımcının verisiyle yapılmıştır. Sosyal medya da beş platformla sınırlandırılmıştır. Dolayısıyla, sadece bu beş platform dışında yer alan platformların da haber edinme amaçı kullanım sıklıklarının incelenmesi ve haber paylaşma davranışlarına bakılması, bu çalışmanın bulgularının genellenebilirliğine katkı sağlayacaktır. Ayrıca, araştırmanın farklı zamanlarda daha fazla örneklem sayısıyla tekrarlanması literatüre daha geçerli bulgular katacaktır. İleride yapılacak çalışmalarda haber paylaşma davranışının altında yatan motivasyonlar, haber edinme amaçlı sosyal medya kullanım sıklığı açısından incelenebilir. Böylelikle hangi sıklık grubundaki bireylerin hangi temel motivasyonlarla haber paylaşma davranışını gerçekleştirdikleri tespit edilebilir.

\section{Etik Beyan}

"Haber Edinme Amaģh Sosyal Medya Kullanm Sıklğgmn Haber Paylaşma Davramısı Üzerindeki Rolü: Bir Saha Calışması" başlıklı çalışmanın yazım sürecinde bilimsel, etik ve alıntı kurallarına uyulmuş; toplanan veriler üzerinde herhangi bir tahrifat yapılmamış ve bu çalışma herhangi başka bir akademik yayın ortamına değerlendirme için gönderilmemiştir. Bu araştırmanın verileri 01.01.2020 tarihinden önce toplandığ1 ve makalenin süreci 2020 yılında başladığından etik kurul kararı zorunluluğu taşımamaktadır.

\section{Kaynakça}

Ali, S. R. ve Fahmy, S. (2013). Gatekeeping and citizen journalism: The use of social media during the recent uprising in Iran, Egypt, and Libya. Media, War and Conflict, 6(1), 55-69, doi: 10.1177/1750635212469906

Aydoğan, F. ve Kırık, A. M. (2012). Alternatif medya olarak yeni medya. Akdeniz Iletişim Dergisi, 18, 58-69. Erişim adresi: https://dergipark.org.tr/tr/pub/akil/issue/48077/607860

Babacan, M. E. (2014). Sosyal medya sonrası toplumsal hareketler. Birey ve Toplum Dergisi, 7(4), 135-160. Erişim adresi: https://dergipark.org.tr/en/download/article-file/40814

Başlar, G. (2013). Yeni medyanın gelişimi ve dijitalleşen kapitalizm. İ̧̧inde M. Akgül ve U. Çağlayan (Edt.), Akademik bilisim konferanst (ss. 823-831). Antalya, Türkiye: İnternet Teknolojileri Derneği Yayını.

Becan, C. (2018). Sosyal medya bağımlılı̆ının haber takibi motivasyonları üzerine etkisi. Erciyes İletişim Dergisi, 5(3), 238-256. doi: 10.17680/erciyesakademia.350085

Bruns, A., Highfield, T. ve Burgess, J. (2013). The Arab spring and social media audiences: English and Arabic Twitter users and their networks. American Behavioral Scientist, 57(7), 871-898. doi: 10.1177/0002764213479374

Bulunmaz, B. (2015). Yeni iletişim teknolojleriyle değişen medya yayıncılığı: Yeni medyada içerik üretimi ve sunumu. İçinde A. Z. Özgür ve A. Şişman (Edt.), İletişim çallşmalar (ss. 325-332). Sakarya: Sakarya Üniversitesi Yayınları.

Calhoun, C. (2013). Ocuppy Wall Street in perspective. British Journal of Sociology, 64(1), 26-38. doi: 10.1111/14684446.1200

Casalo, L.V., Flavian, C. ve Ibanez-Sanchez, S. (2020). Be creative, my friend! Engaging users on Instagram by promoting positive emotions. Journal of Business Research. doi: 10.1016/j.jbusres.2020.02.014

Castells, M. (2005). Ağ toplumunun yükeselişi enformasyon çağg: Ekonomi, toplum ve kültür (Çev: E. Kullç). İstanbul: Bilgi Üniversitesi Yayınlar1.

Chen, X., Sun, M., Wu, D. ve Song X. Y. (2019). Information-sharing behavior on WeChat moments: The role of anonymity, familiarity, and intrinsic motivation. Frontiers in Psychology, 10, 1-15. doi: 10.3389/fpsyg.2019.02540

Creswell, J. W. (2014). Educational researcb: Planning, conducting, and evaluating quantitative and qualitative research. New York: Pearson.

Crowley D. ve Heyer P. (2014). İletisim taribi: Teknoloji, kültür, toplum (Çev: B. Ersöz). Ankara: Siyasal Kitabevi.

Çakır, H. (2018). Kırgızistan-Türkiye Manas Üniversitesi öğrencilerinin sosyal medya kullanım alışkanlıkları. MANAS Sosyal Araştrmalar Dergisi, 3(7), 539-563. $\quad$ Erişim adresi: https://dergipark.org.tr/tr/pub/mjss/issue/43001/520570

De-Laguno-Alarcon, C., Sierra-Herrezuelo, P. ve Rojas-de-Gracia, M. (2019). Results-oriented influencer marketing manual for the tourism industry. İçinde K. Mezghani ve W. Aloulou (Edt.), Business transformations in the era of digitalization (ss. 249-275). Hershey: IGI Global. doi: 10.4018/978-1-5225-7262-6.ch014

Elvestad, E., Philips, A. ve Feuerstein, M. (2018). Can trust in traditional news media explain cross-national differecens in news exposure of young people online? Digital Journalism, 6(2), 216-235. doi: 10.1080/21670811.2017.1332484

Erdoğan, B. Z., Özata, F. Z., Doğan, S. ve Şaşmaz, A. (2017). Konum tabanlı mobil Swarm uygulaması üzerinden paylaşım motivasyonlarının incelenmesi. Tüketici ve Tüketim Arasstrmalar Dergisi, 9(2), 379-400. Erişim adresi: http://betadergi.com/ttad/yonetim/icerik/makaleler/151-published.pdf

Eren, V. ve Aydın A. (2014). Sosyal medyanın kamuoyu oluşturmadaki rolü ve muhtemel riskler. KMÜ Sosyal ve Ekonomike Arasstrmalar Dergisi, 16, 197-205. Erişim adresi: https://dergipark.org.tr/tr/download/articlefile/107219 
Fukuyama, F. (2000). Büyü̈k çözülme, insanın doğası ve toplumsal düzenin yeniden olusturulması (Çev: H. Kaya). İstanbul: Profil Yayincilik.

Gabore, S. M. ve Xiujun, D. (2018). Opinion formation in social media: The influence of online news dissemination on Facebook posts. South African Journal for Communication Theory and Research, 44(2), 20-40. doi: 10.1080/02500167.2018.1504097

Gegez, E. (2010). Pazarlama araştırmaları. İstanbul: Beta Yayıncılık.

Hair, J. F., Black, W. C., Babin, B. J. ve Anderson, R. E. (2014). Multivariate data analysis. New York: Pearson Education Limited.

Jenkins, H. (2006). Convergence culture where old and new media collide. New York: New York University Press.

Kalayc1, S.. (2017). SPSS uygulamal çok değiskenli istatistik teknikleri. Ankara: Dinamik Akademi Yayın Dağıtım.

Kara, T. (2013). Sosyal medya endüstrisi. İstanbul: Beta Yayınc1lık.

Karahasan, F. (2012). Taşlar yerinden oynarken: Dijital pazarlamanın kuralları. İstanbul: Doğan Egmont Yayıncılik.

Karaman, M. ve Önder, M. (2017). Yurttaş gazeteciliğinin ana akım medyaya etkisi: Whatsapp ihbar hatları örneği. Erciyes İletişim Dergisi, 5(2), 164-180. doi: 10.17680/erciyesakademia.312528

Karnowski, V., Leonhard, L. ve Kümpel, A. S. (2018). Why users share the news: A theory of reasoned action-based study on the antecedents of news-sharing behavior. Communication Research Reports, 35(2), 91-100. doi: 10.1080/08824096.2017.1379984

Kılıç, D. ve İspïr, B. (2020). Sosyal medyada haber içeriklerine güven ve kullanıcı motivasyonları. Kurgu, 28(1), 269288. Erişim adresi: https://dergipark.org.tr/en/pub/kurgu/issue/55448/719374

Kim, J., Namkoong, K. ve Chen, J. (2020). Predictors of online news-sharing intention in the U.S and South Korea: An application of the theory of reasoned action. Communication Studies. doi: 10.1080/10510974.2020.1726427

Köseoğlu, Y. ve Al, H. (2014). Bir siyasal propaganda aracı olarak sosyal medya. Akademik Incelemeler Dergisi, 8(3), 103-125. Erișim adresi: https://dergipark.org.tr/tr/pub/akademikincelemeler/issue/1543/18945

Kümpel, A. S., Karnowski, V. ve Keyling, T. (2015). News sharing in social media: A review of current research on news sharing users, content, and networks. Social Media + Society. doi: 10.1177/2056305115610141

Lee, C. S. ve Ma, L. (2012). News sharing in social media: The effect of gratifications and prior experience. Computers in Human Behavior, 28(2), 331-339. doi: 10.1016/j.chb.2011.10.002

Nah, S., Namkoong, K., Record, R. ve Van Stee, S. K. (2017). Citizen journalism practice increases civic participation. Newspaper Research Journal, 38(1), 62-78. doi: 10.1177/0739532917698444

Neuman, W. R. (2018). Dijital fark, gündelik hayatta dijitalleşme ve medya etkileri kuram (Çev: G. Metin). İstanbul: The Kitap Yayınları.

Özata, F. Z., Kılıçer, T. ve Ağlargöz, Y. (2014). Müptelalardan mesafelilere sosyal ağ sitesi kullanıcısı gençler: Kullanma motivasyonları ve davranışları açısından profilleri. Anadolu Üniversitesi Sosyal Bilimler Dergisi, 14(3), 1938. doi: $10.18037 /$ ausbd. 85187

Palekar, S. ve Sedera, D. (2018). Influence of social broadcasting networks on news consumption. Australasian Journal of Information Systems, 22, 1-29. Erişim adresi: https://journal.acs.org.au/index.php/ajis/article/download/1707/828

Pallant, J. (2011). SPSS survival manual: A step by step guide to data analysis using SPSS. New York: Open University Press.

Salgado, S. ve Bobba, G. (2019). News on events and social media: A comparative analysis of Facebook users' reactions. Journalism Studies, 20(15), 2258-2276. doi: 10.1080/1461670X.2019.1586566

Segado-Boj, F., Diaz-Campo, J. ve Redondo, R. Q. (2019). Influence of the "news finds me" perception on news sharing and news consumption on social media. Communication Today, 10(2), 90-104. Erişim adresi: https://www.communicationtoday.sk/wp-content/uploads/07.-SEGADO-BOJ-et-al.-\%E2\%80\%93-CT-22019.pdf

Song, H., Zuniga, H. G. ve Boomgaarden, H. G. (2020). Social media news use and political cynicism: Differential pathways through "news find me" perception. Mass Communication and Society, 23(1), 47-70. 10.1080/15205436.2019.1651867

Sposito, V. A., Hand, M. L. ve Skarpness, B. (1983). On the efficiency of using the sample kurtosis in selecting optimal lpestimators. Communications in Statistics-simulation and Computation, 12(3), 265-272. doi: $10.1080 / 03610918308812318$

Su. M., Liu, J. ve McLeod, D. M. (2019). Pathways to news sharing: Issue frame perceptions and the likelihood of sharing. Computers in Human Behavior, 91, 201-210. doi: 10.1016/j.chb.2018.09.026.

Swart, J., Peters, C. ve Broersma, M. (2019). Sharing and discussing news in private social media groups. Digital Journalism, 7(2), 187-205. doi: 10.1080/21670811.2018.1465351

Thompson, N., Wang, X. ve Daya, P. (2019). Determinants of news sharing behavior on social media. Journal of Computer Information Systems. doi: 10.1080/08874417.2019.1566803

Uğurhan, Y., Genç Kumtepe, E., Kumtepe, A. ve Saykıl1, A. (2020). From media literacy to new media literacy: A lens into open and distance learning context. Turkish Online Journal of Distance Education. 21, 135-151. doi: $10.17718 /$ tojde. 770953

Ünal, R. (2019). Anaakım medyada kullanıcı türevli içeriğin izini sürmek: NTV ve Star TV Whatsapp ihbar hatları üzerine bir inceleme. Mersin Üniversitesi Sosyal Bilimler Enstitüsü Dergisi, 2(2), 34-43. Erişim adresi: https://dergipark.org.tr/en/pub/meusbd/issue/49378/586961 
Ürkmez, D. (2020). Dijital aktivizm olarak sosyal medyada boykot çağrıları: Watsons krizi örneği. Gelişim Üniversitesi Sosyal Bilimler Dergisi, 7(1), 106-125. doi: 0.17336/igusbd.541514

Van Dijk, J. (2018). A ̆ toplumu (Çev: Ö. Sakin). İstanbul: Kafka Yayınevi.

Yaşar, I. H. (2020). Sosyal medya ve siyaset. Ankara: Orion Akademi.

Yavaşçalı, A. H. ve Uğurhan, Y. Z. C. (2019). Neden kullanıcılar Twitch TV üzerinde yayıncılara bağış yapar? Twitch TV kullanıcıları üzerinde ampirik bir araştırma. Gümüşhane Üniversitesi Iletişim Fakültesi Elektronik. Dergisi, 7(2), 646-676. doi: 10.19145/e-gifder.561050

Youmans, W. L. ve York, J. C. (2012). Social media and activist toolkit: User agreements, corporate interest, and the information infrastructure of movements. Journal of Communication, 62(2), 315-329. doi: 10.1111/j.14602466.2012.01636.x

\section{EXTENDED ABSTRACT}

Social media is at the center of life for today's individual. All kinds of human activities are somehow related to the internet and social media. It is seen that a substantial part of the commercial activities, whether wholesale or retail, take place over the internet and related social media applications. Social media's features such as being bidirectional and interactive and allowing real-time communication have enabled the communication to break the chains of time and place. Mobile internet, smart mobile devices and its applications allow today's individuals to be more accessible to others by including them in the network anytime and anywhere. The most important factor that makes social media so important is its potential to turn even ordinary people into mass streamers. Social media platforms are interactive environments where ordinary people, as a personal stream medium, follow each other, identify themselves against various problems and situations, and react collectively.

One of the most important functions of mass media is that the society is aware of each other and important events. In addition, social media contributes to the spread of different ideas. Thus, mass media provide information and news that will form the basis of discussions on nearly every subject, and it helps to clarify the social mind. However, traditional mass media such as TV, newspapers, radio, and magazines differ from social media in a very basic point. The point is that social media platforms have a bidirectional and interactive structure. This difference of social media has led the individual, who was once passive, to have and active role in the face of mass media. Social media platforms are primarily user-centered, moreover, it is noteworthy that the users create the content on these platforms. The individual not only consumes the content in the current environment with the development, but also has a position to produce it at the same time as a prosumer. Hence, the individual has now become an activeparticipant/streamer with social media. By using the opportunities provided by social media, s/he started to share on what is happening around him/her on social media platforms.

Apart from other usage purposes, social media are considered to serve two purposes, which this study focuses on. The first is the use of these media for the purpose of acquiring news, and the second is the mediation of the users to share the events that they think it is newsworthy with the masses. Getting news helps people to be informed about all kinds of events by considering different points of view and to form their opinions. On the other hand, sharing news is a part of people's ability to express their thoughts freely. People witnessing traffic accidents, terrorist acts, suicide, theft or public events, etc. can share all kinds of newsworthy events in different formats from their social media accounts. Furthermore, people can engage in citizen journalism by sending the content to the hotlines of press organizations (WhatsApp hotlines, etc.), thereby affecting the mainstream media and becoming a part of the news production process. Consequently, at the end of the day, along with being a part of the news production, people can also become the subject of another news due to the news they make.

In this study, a cross-sectional quantitative research method was employed to examine the use of social media platforms that are determined by We Are Social and Hotsuite as top five social media platforms used in Turkey in 2020, for the purpose of getting and sharing news. A convenience sampling method was used and the data of 397 people who voluntarily participated in the study were analyzed. The participants were divided into clusters according to the frequency of their use of social media platforms to get and share news, and the study aimed to reveal a profile for today's individual by examining the relationship of these clusters with demographics (gender, age, educational degree, monthly income and time spent daily on social media). In addition, news sharing behavior was scrutinized by evaluating it in terms of demographics.

According to the results, it was determined that the most frequently used social media platform to get news was WhatsApp and the least used one was Facebook. In addition, both women and men used social 
media with similar manner to get news. However, the frequencies differed significantly in terms of age, educational degree, monthly income and time spent daily on social media. Regarding educational background, those with low frequency of getting and sharing news largely had educational degrees at high school and below levels, while those with medium and high frequency mainly had degrees at graduate and postgraduate levels. In the context of time spent daily on social media, it was determined that those who spent less time on social media, use social media with low frequency to get news, whereas those who spent more time exhibited medium and high frequency to get news. Those who used social media with high frequency to get news tended to share more news than those who had low frequency. Considering demographics, it was observed that news sharing behavior on social media was at similar frequency regardless of gender, age, educational degree, and monthly income. However, when it comes to time spent daily on social media, it was found that those who spent more time tended to share more news. In other words, the results suggest that those who spend more time on a daily basis have become more of a news streamer. 